\title{
Groundwater quality and its variation along irrigation canals in Pakistan
}

\author{
M. Latif \\ Centre of Excellence in Water Resources Engineering, \\ University of Engineering and Technology, Lahore, Pakistan
}

\begin{abstract}
The Indus Basin of Pakistan is thickly populated and supports a rapidly growing population of 170 million. More than 90 percent of food production in the country is contributed by the irrigated agriculture which is presently facing many challenges and hardships such as salinity, extreme scarcity of canal water, groundwater mining and degradation of its quality. Water and soil samples were collected in a canal command area to assess and analyze the quality of pumped groundwater and soil salinity respectively. Data of crop yield and income of the farmers was also collected. The results show that electrical conductivity (EC) of groundwater increases from upper to lower reaches along all the irrigation channels i.e. the main, secondary and tertiary canals. The groundwater was found suitable only in about one-half of the command area. In rest of the area groundwater is either marginally fit for irrigation or it is hazardous (unfit). Similarly the soil salinity also increased from upper to lower reaches along the irrigation canals. The soil salinity almost follows the pattern of groundwater salinity. The crop yield and net income of the water users decreased along all the irrigation channels (i.e. the main, secondary and tertiary canals) but decrease in net income was much more than decrease in crop yield. Due to less canal water supply along the lower reaches of the irrigation channels, the downstream water users pump more groundwater to meet their irrigation needs. The deteriorating groundwater quality along the lower reaches of the irrigation channels further adds misery to the downstream farmers by degrading productivity of their lands caused by excessive use of saline groundwater. Location of the water users along the canal irrigation system had significant impact on their crop yield as well as income and these parameters decreased from head of the irrigation channels towards their lower reaches. For example, the net income of the tail-end farmers
\end{abstract}


was only $43 \%$ to $59 \%$ of the head-end farmers. The lower income of the tail-end farmers has many adverse impacts on socio-economic conditions of these farmers. To improve the condition of the downstream farmers, some measures are suggested in this paper.

Keywords: irrigation water, soil salinity, cost of irrigation, income, productivity, groundwater policy and options.

\section{Introduction}

Irrigation is indispensable in arid and semi-arid climates. Importance of irrigated agriculture can be recognized from the fact that world-wide a lion's share (72\%) of water is used alone by the irrigation sector. Irrigation provides a source of livelihood to the rural settings in arid and semi-arid countries. In Pakistan irrigated agriculture contributes around 90 percent of food production. Pakistan possesses one of the largest contiguous gravity flow irrigation networks in the world. This irrigation system has been designed and constructed with the objective of spreading water over the maximum area in order to serve more and more water uses without any flexibility to meet varying irrigation demands. Thus water is not supplied according to crop water requirements but rather it is a supply-based system characterized for deficit irrigation. The designed cropping intensities were generally kept low, i.e. $60-80 \%$, but present intensities are 125 $150 \%$ or even more in many canal commands. The various components of water distribution are barrages, main canals, secondary- and tertiary canals. Water is diverted from the barrages into the main canals and other distribution networks. Canal water is supplied continuously up to the outlets on the tertiary canals (watercourses), but from there onward it is distributed in a weekly or 10-day rotation called 'warabandi' within the watercourse command areas. The command area, which may vary from 80 to 320 ha, determines the size of an outlet. Each water user gets his water share depending on his land-holding on his turn if water is available in the distribution network. However, no compensation is given for missed turns to the water users.

Pakistan's canal irrigation system operates largely in a water-short environment. The need to use the scarce water resources judiciously and economically has been the main concern of system designers from the early days of irrigation development in the country. Productivity is largely affected by the availability of surface irrigation water supplies. Unreliability, insufficiency, high losses and inequitable distribution of canal water are some of the main constraints of the irrigation system. These factors affect the income-generating capacity of the farmers resulting in low crop yields, productivity and profitability especially in areas where groundwater is saline. Because of these factors, the risk of falling into the poverty trap increases, and has shown a significant increase over recent years for the farmers whose livelihood is entirely dependent on irrigated agriculture.

There is a wide gap between the potential and the actual yields obtained across different farms within a canal command area. The irrigation system was designed to supply water equitably, but many studies [1-5] have confirmed that 
there is much inequity and unreliability in distribution of canal water. The inequity and unreliability are present at different levels, i.e. within a tertiary and secondary and along the main canals. Normally, the condition of the water supply is satisfactory at the head of the system, but it deteriorates towards the tail ends of the system in different ways. The downstream farmers not only get less canal water (although they are authorized to receive the same amount of canal water as the head-enders) but the groundwater, if available, that they pump is also of inferior quality. Crop yields of these farmers do not only suffer due to canal water shortage but also due to saline groundwater that is used to supplement the surface water, thus causing salinity and sodicity problems. The situation is so obvious that one can clearly distinguish the miserable conditions of the water uses located along lower reaches of the irrigation system even when traveling along the irrigation channels. According to some studies, irrigation development is a more effective means to alleviate poverty than any other type of public development in rural areas in arid and semi-arid climates. But poor performance, inefficiency and inequality of the irrigation system may not be effective in overcoming poverty, as happened in Pakistan [6]. Thus income o the farmers and their poverty can be directly related to the performance of irrigation systems, as is demonstrated in recent studies by Latif [7], Hussain et al. [8], Bhattarai et al. [9]. The main objective of this article is to demonstrate that quality of groundwater, soil salinity, cost of pumping groundwater and income of the farmers vary along the irrigation canals in Pakistan.

\section{Methodology and data collection}

This study was undertaken in the command area of main branch lower (MBL) canal located in central Punjab, Pakistan. It is a perennial canal. The design discharge of this canal is $48.5 \mathrm{~m}^{3} \mathrm{~s}^{-1}$ and it commands an area of 0.134 million ha. Six secondary canals (distributary) were selected: two each at the head, middle and tail of the main canal. The main features of the selected secondary canals are given in table 1. For detailed analysis, nine tertiary canals (watercourses) were selected on each secondary channel: three each at its head, middle and tail reach respectively. Further, nine farmers were selected at each selected tertiary canal (again three each at head, middle and tail-end respectively). Thus total farmers selected on each secondary canal were 81 ( $9 \mathrm{X}$ 9), whereas 486 ( 6 X 81) farmers were selected on all the six secondary canals and 54 tertiary canals in the study area.

The canal water is supplied to the farmers by the Irrigation Department who manages, operates and maintains the entire irrigation network except the tertiary canals (watercourses) which are maintained by the farmers collectively. Data of the irrigation system and the irrigated area were collected from the Irrigation Department. A comprehensive proforma was designed to collect data and information from the selected farmers regarding number of irrigations applied, source of irrigation water, farming operations, inputs applied, total expenses, and yield of wheat crop for three seasons (2005 to 2007). Groundwater samples were collected from tube wells of the farmers once during each season. 
Table 1: $\quad$ Main features of the secondary canals selected.

\begin{tabular}{|c|c|c|c|c|c|c|}
\hline No. & $\begin{array}{c}\text { Location on } \\
\text { the main } \\
\text { canal }\end{array}$ & $\begin{array}{c}\text { Name of } \\
\text { distributary } \\
/ \text { minor }\end{array}$ & $\begin{array}{c}\text { Off taking } \\
(\text { R.D. })^{\mathrm{a}}\end{array}$ & $\begin{array}{c}\text { Command } \\
\text { area (ha) }\end{array}$ & \multicolumn{2}{|c|}{ Design discharge } \\
\cline { 5 - 7 } & & & & & & \\
\hline 1 & Head & Athail pur & $\left.27313 \mathrm{~L}^{\mathrm{b}} / \mathrm{sec}\right)$ & 8490 & 1.93 & 68 \\
\hline 2 & & Lulliani & $303810 \mathrm{~L}$ & 4345 & 1.40 & 49.3 \\
\hline 3 & Middle & Chinna & $359020 \mathrm{~L}$ & 11792 & 3.96 & 140 \\
4 & & Zaferke & $372937 \mathrm{R}^{\mathrm{b}}$ & 6721 & 1.76 & 62 \\
\hline 5 & Tail & Rose & $495155 \mathrm{~L}$ & 5498 & 2.01 & 71 \\
6 & & Vahn & $459100 \mathrm{~L}$ & 8457 & 2.89 & 102 \\
\hline
\end{tabular}

${ }^{\mathrm{a}} \mathrm{RD}$ stands for reduced distance. $1 \mathrm{RD}=1000 \mathrm{ft}=304.8 \mathrm{~m}$.

${ }^{\mathrm{b}} \mathrm{L}$ and $\mathrm{R}$ means left or right side of the canal.

Similarly, soil samples were also collected from one field of the selected farmers along the tertiary canals. Six soil samples were collected from each sampling site up to $90 \mathrm{~cm}$ depth with an interval of $15 \mathrm{~cm}$. Chemical analyses of these samples were carried out to determine the quality of groundwater and salinity status of the soil.

\subsection{Cost of production}

Cost of production consists of fixed cost and variable cost. The latter consists of cost of land preparation, cost of seed, cost of sowing, cost of fertilizers, cost of pesticides, cost of wedicides, cost of irrigation, cost of harvesting and threshing. The cost of irrigation (abiana) includes canal water charges and groundwater pumping cost. The canal water charges are fixed @ Rs. ${ }^{1} 135$ per ha (Rs 55 per acre) except the tail-ends of the secondary canals where the canal water is charged @ Rs. 75 per ha (Rs. 30 per acre) (one US dollar $\approx$ Rs. 61 in 2007). Irrigation from groundwater by tube well costs approximately @ Rs.150 per hour in the study area during years 2005-07. Cost of irrigation from groundwater was calculated knowing time of irrigation by tube well which varied from 5 to 9 hours per ha depending on discharge of the tube wells.

\section{Results and discussion}

\subsection{Number of irrigation by source}

Source of irrigation water is canal (surface) water and groundwater (tube well). Canal water supply is fixed per unit irrigated land for all the farmers regardless of their location on the irrigation network. But in reality, supply of canal water decreases monotonically from head to tail of the tertiary canals as demonstrated by $[3,5,10]$ and many others. The number of irrigation applied from canal water and groundwater in 54 tertiary canals are given in table 2. It is evident from this table that the maximum number of irrigations applied from canal water is four at head of the main- and the secondary canals. On the other hand, the situation was so worse at the tails of the secondary canals that only one or no 
Table 2: Average number of irrigations applied from canal water and groundwater.

\begin{tabular}{|c|c|c|c|c|c|c|c|}
\hline \multirow{2}{*}{ Location along } & \multicolumn{6}{|c|}{ Source of irrigation } \\
\cline { 3 - 9 } & \multicolumn{5}{|c|}{ Canal water } & \multicolumn{3}{c|}{ Groundwater } \\
\cline { 3 - 9 } & \multicolumn{5}{|c|}{ Location along the watercourses } \\
\hline \multirow{2}{*}{$\begin{array}{c}\text { Main } \\
\text { canal }\end{array}$} & $\begin{array}{c}\text { Secondary } \\
\text { canals }\end{array}$ & Head & Middle & Tail & Head & Middle & Tail \\
\hline \multirow{3}{*}{ Head } & Head & 4 & 3 & 2 & 1 & 1 & 2 \\
\cline { 2 - 9 } & Middle & 3 & 2 & 2 & 1 & 2 & 2 \\
\cline { 2 - 9 } & Tail & 1 & 1 & 0 & 3 & 4 & 4 \\
\hline \multirow{3}{*}{ Middle } & Head & 4 & 3 & 2 & 1 & 1 & 2 \\
\cline { 2 - 8 } & Middle & 3 & 2 & 2 & 1 & 2 & 2 \\
\cline { 2 - 8 } & Tail & 1 & 1 & 0 & 3 & 3 & 4 \\
\hline & Head & 3 & 2 & 2 & 1 & 2 & 2 \\
\cline { 2 - 8 } & Middle & 3 & 2 & 2 & 2 & 2 & 3 \\
\cline { 2 - 8 } & Tail & 1 & 1 & 0 & 3 & 3 & 4 \\
\hline
\end{tabular}

irrigation could be applied from canal water. To meet the crop water requirements, the farmers are compelled to pump more groundwater. Thus, there is corresponding increase in the number of irrigations from groundwater that varied from one to four from head reaches of the channels toward their tail ends.

There could be many reasons for the inequity of canal water supply such as seepage losses and poor maintenance of the irrigation channels but there is a design flaw in the allocation of water to the water users that is based on Malhotra's [11] model on which the system has been designed in the subcontinent of Pakistan and India. Seepage loss has not been considered in the Malhotra's model, resulting in more seepage losses with increasing length of the tertiary canals and consequently a decreasing amount of water is received by the downstream water users. This situation can be improved if the seepage losses which have been ignored in the above model are accounted for and the water allocation scheduled is revised accordingly. This can be accomplished if water allocation is changed from constant time to variable time basis (i.e. less time to the head enders and more to the tail enders) as suggested by some researchers $[3$, $5,10,12]$.

\subsection{Quality of groundwater}

The electrical conductivity (EC) of groundwater varied greatly and it ranged from less than 1 to more than $10 \mathrm{dS} \mathrm{m}^{-1}$ in the study area. The groundwater EC tends to increase from head to tail end along almost all the canals as depicted in figure 1. Average EC of groundwater at head reaches of the tertiary canals is $1.36 \mathrm{dS} \mathrm{m}^{-1}$ and it increases to 1.90 and $2.47 \mathrm{dS} \mathrm{m}^{-1}$ respectively at the middle and tail reaches respectively. 


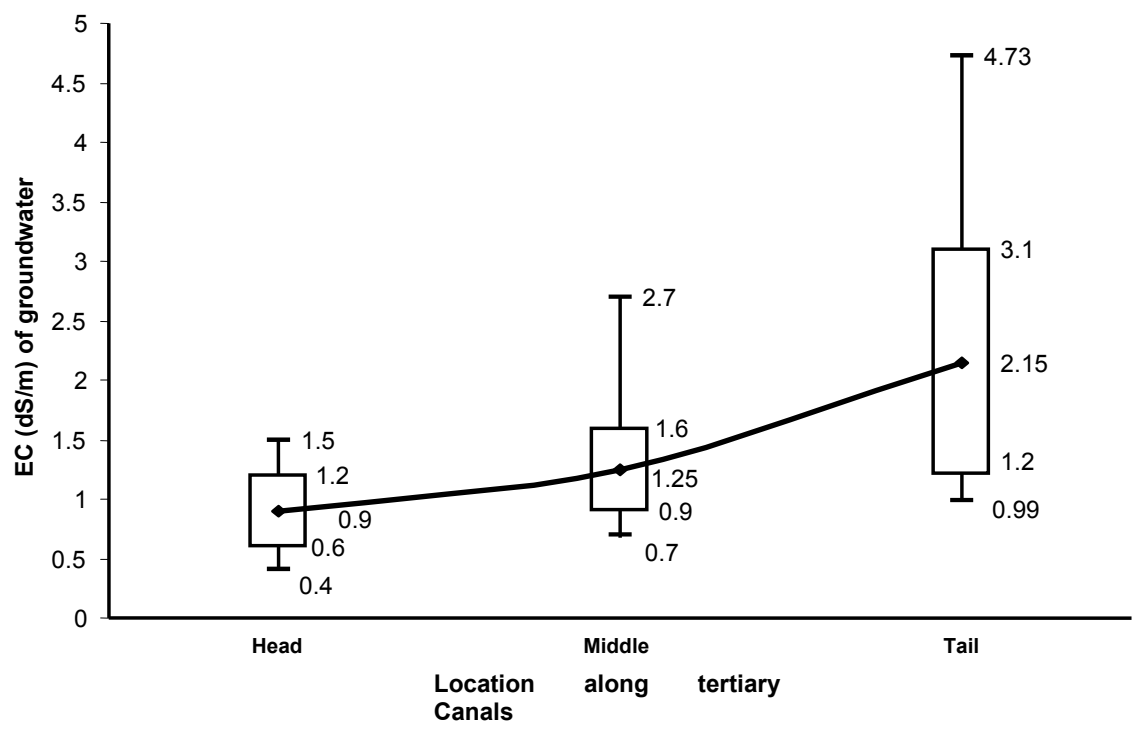

Figure 1: Variation of groundwater quality along the irrigation channels in the study area.

The groundwater EC data may be classified into suitable, marginal and unsuitable classes. The results show that $53 \%$ of the water samples had EC below $1.5 \mathrm{dS} \mathrm{m}^{-1}$, whereas $32 \%$ of the samples had EC in the range $1.5-3.0 \mathrm{dS}$ $\mathrm{m}^{-1}$ and $15 \%$ of the samples had EC greater than $3.0 \mathrm{dS} \mathrm{m}^{-1}$. According to FAO [13] guidelines for irrigation (salinity) water quality, EC of irrigation water between 0.75 to $3 \mathrm{dS} \mathrm{m}{ }^{-1}$ causes an "increasing problem", whereas a "severe problem" is caused if EC exceeds $3 \mathrm{dS} \mathrm{m}^{-1}$. The EC is greater than $1.5 \mathrm{dS} \mathrm{m}^{-1}$ in almost one-half of the study area, thus causing a reduction in crop yield, degradation of soil and many other socio-environmental issues.

\subsection{Groundwater quality and soil salinity}

The quality of canal water is good and same everywhere but quality of groundwater deteriorates along the lower reaches of the irrigation channels resulting in increasing salinity and alkalinity of the soil. Data of electrical conductivity $\left(\mathrm{EC}_{\mathrm{e}}\right)$, sodium absorption ratio $(\mathrm{SAR})$ and residual sodium carbonates (RSC) of the soil samples are given in table 3. As stated earlier, groundwater becomes more saline along lower reaches of the irrigation channels. The $\mathrm{EC}_{\mathrm{e}}$ of soil at head reaches of the tertiary canals is $1.19 \mathrm{dS} \mathrm{m}^{-1}$ and it increases to 1.29 and $2.27 \mathrm{dS} \mathrm{m}^{-1}$ at their middle and tail reaches respectively. The soil salinity is directly related to the quality of groundwater in the study area. (For detailed discussion, see Latif and Ahmad [14]). Thus the down reach farmers are not only unlucky in receiving less canal water but the quality of the groundwater which they pump also deteriorates. It is clearly evident from the above data that the groundwater quality and soil salinity are not the same 
Table 3: $\quad$ Soil salinity parameters of the tertiary canals in the study area.

\begin{tabular}{|c|c|c|c|c|}
\hline $\begin{array}{c}\text { Watercourse } \\
\text { number }\end{array}$ & $\begin{array}{c}\text { Location at } \\
\text { secondary } \\
\text { canal }\end{array}$ & $\begin{array}{c}{ }^{1} \mathrm{ECe} \\
\left(\mathrm{dS} \mathrm{m} \mathrm{m}^{-1}\right)\end{array}$ & RSC & SAR \\
\hline 3 & \multirow{7}{*}{ Head } & 0.80 & 1.57 & 2.15 \\
\hline 11 & & 1.93 & 0.00 & 3.06 \\
\hline 20 & & 1.27 & 2.89 & 3.38 \\
\hline 28 & & 0.82 & 3.32 & 1.79 \\
\hline 38 & & 0.85 & 2.44 & 2.62 \\
\hline 46 & & 1.50 & 2.25 & 2.58 \\
\hline Average & & 1.19 & 2.08 & 2.60 \\
\hline 4 & \multirow{7}{*}{ Middle } & 0.77 & 2.02 & 2.70 \\
\hline 13 & & 1.56 & 1.82 & 4.14 \\
\hline 24 & & 1.24 & 2.01 & 2.18 \\
\hline 31 & & 1.37 & 2.86 & 2.65 \\
\hline 42 & & 0.59 & 2.84 & 0.70 \\
\hline 51 & & 2.19 & 0.00 & 5.26 \\
\hline Average & & 1.29 & 1.93 & 2.94 \\
\hline 9 & \multirow{7}{*}{ Tail } & 1.64 & 5.63 & 9.11 \\
\hline 16 & & 1.38 & 2.59 & 6.32 \\
\hline 25 & & 2.07 & 0.56 & 7.81 \\
\hline 36 & & 2.15 & 2.97 & 5.93 \\
\hline 45 & & 4.42 & 0.00 & 8.43 \\
\hline 53 & & 1.93 & 0.27 & 3.52 \\
\hline Average & & 2.27 & 2.01 & 6.85 \\
\hline \multicolumn{2}{|c|}{ Overall Average } & 1.6 & 2.0 & 4.1 \\
\hline \multicolumn{2}{|c|}{ Standard deviation } & 0.87 & 1.45 & 2.45 \\
\hline
\end{tabular}

${ }^{1}$ The $\mathrm{EC}_{\mathrm{e}}$ refers to the electrical conductivity of the soil saturation extract.

everywhere in the study area but they vary from low to higher values along the irrigation channels. The use of more salty groundwater further deteriorates the productivity of their lands.

\subsection{Cost of irrigation water}

Presently the cost of canal water is Rs. 135 per ha for whole season for the wheat crop at head and middle of the secondary canals (distributaries) while it is Rs. 75 per ha at their tails. The groundwater pumping costs Rs. 150 per hour (in years $2005-07$ ) and it takes 5 to 8 hours to irrigate one hectare. The cost of irrigation from groundwater varied greatly along the canals depending on their location on the irrigation network. The groundwater irrigation cost varied from less than Rs. 500 at heads of the main- and secondary canals to more than Rs. 4000 per ha at their tail ends. Reason for this increase is that the farmers located at lower reaches of the tertiary- and secondary canals do not get their due share of canal water. Thus they have no other option except pumping more costly groundwater 
resulting in increase of their irrigation cost. Consequently, the cost of production of these farmers is also increased resulting in their less income.

The average cost of irrigation by pumping groundwater along the tertiary-, secondary- and the main canals is plotted in figure 2 for more elaboration. It is clearly depicted in this figure that the cost of irrigation from groundwater increases almost 2-6 times along the lower reaches of the irrigation system at all levels i.e. along the tertiary canals, the secondary- and the main canals. Figure 3 shows that cost of irrigation from groundwater is many times more (up to 27 times) than the cost of canal water irrigation.

The net income per ha from wheat crop and cost of irrigation for all the tertiary canals are plotted in figure 4. Six distinct cycles in the figure are indicative of the six secondary canals along the main canal. The cost of irrigation from groundwater is low near the heads of the secondary canals and it increases towards their tail ends as discussed earlier as well. It is evident from this figure that cost of irrigation increases from head to tail reaches of all the six secondary canals and there is corresponding decrease in the net income of the farmers. Decreasing trend of the net income is also depicted in the figure which is indicated by the decreasing trend of the curve from head to tail of the irrigation channels.

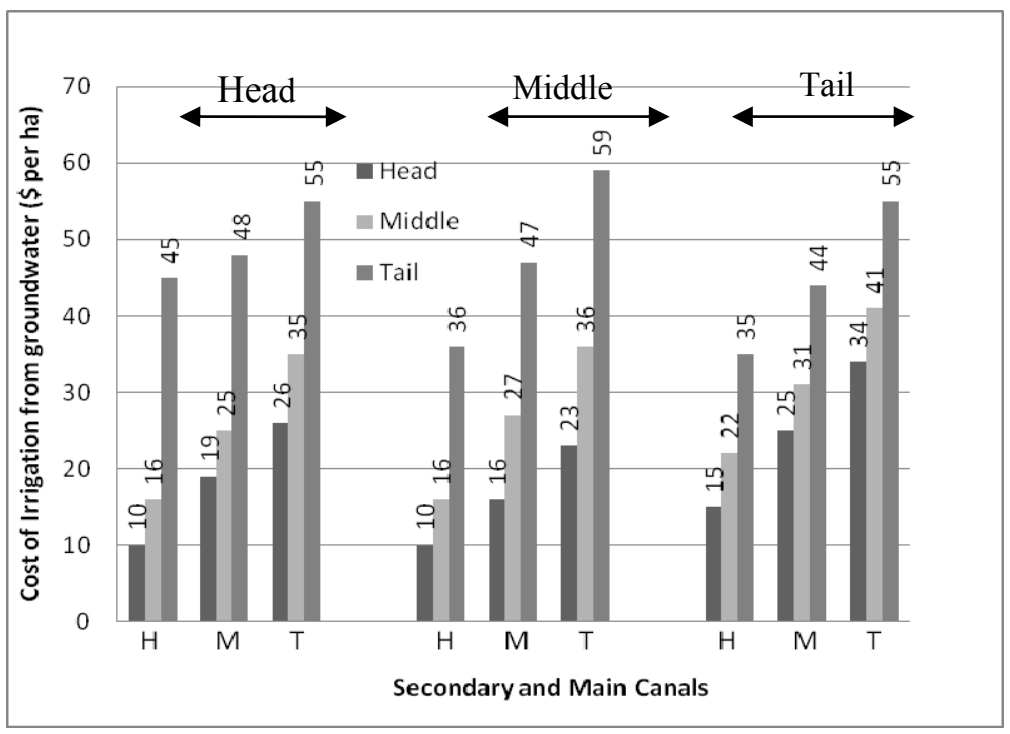

Figure 2: Cost of pumping groundwater for irrigation along different secondary canals located at head, middle and tail of the main canal. 


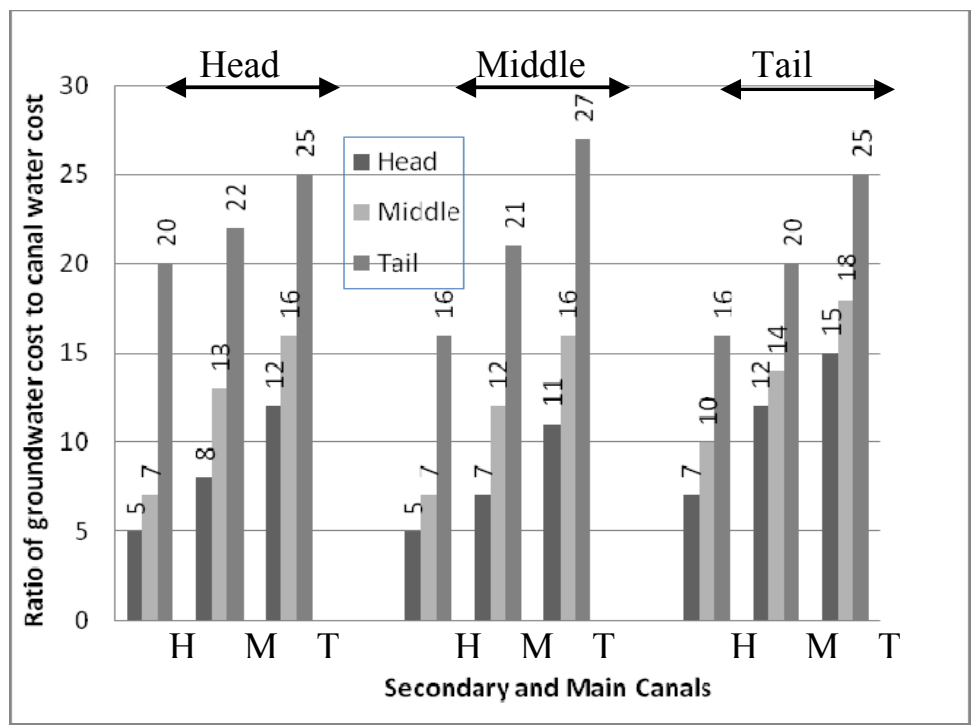

Figure 3: Ratio of irrigation cost from groundwater to canal water along different secondary canals located at head, middle and tail of the main canal.

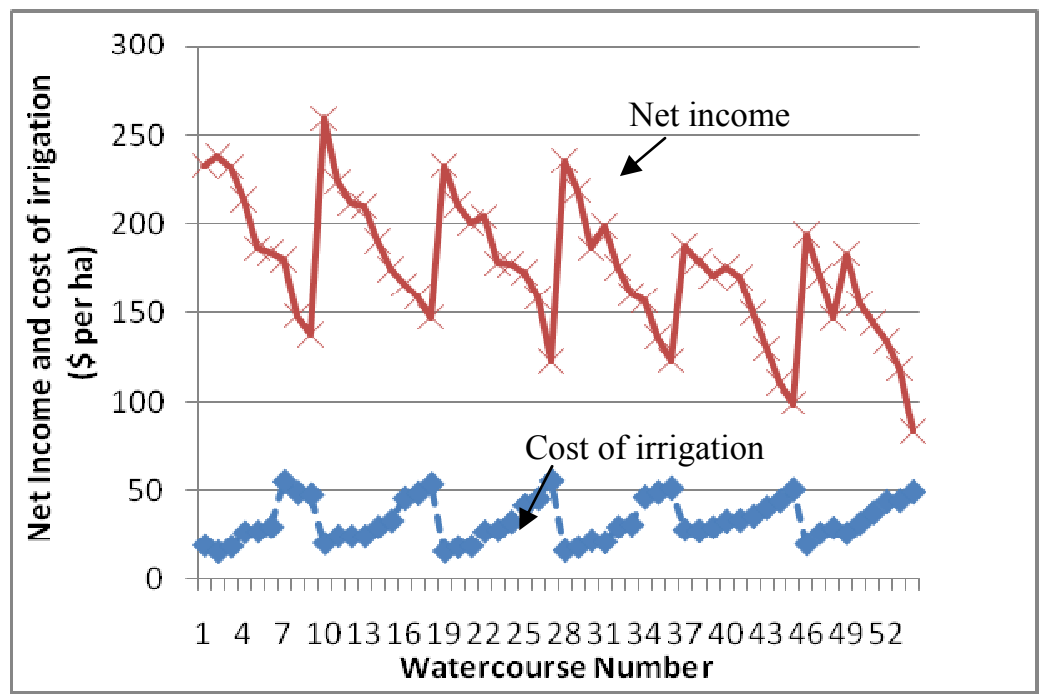

Figure 4: Net income and cost of irrigation along different secondary and tertiary canals. 


\subsection{Policies and options}

To rectify the issues discussed above, different policies and options including but not limiting to water reallocation, integrated management of surface water and groundwater, redefining surface water charging policy, participatory irrigation management, institutional reforms and installation of community tube wells at selected locations would help to empower the situation. Reallocation of existing water rights may not be possible due to legal implications. Availability of additional surface water to the existing canal irrigated areas may not be possible due to three reasons: i) due to scarcity of canal water, ii) lack of storage reservoirs, and iii) new areas awaiting for development in the country. Presently there is no incentive for the farmers for water conservation and making efficient water use. The minimal water charges i.e. 'abaina' is levied on the basis of area planted under different crops. Enhancing canal water price and tying it to the amount of water delivered to the end users may help to improve the situation. Installation of community tube wells at heads of the irrigation channels will help to overcome the quality issue of the pumped water. Providing subsidies and special credits for fertilizers, chemical amendments and other agriculture inputs to the downstream water users will restore their sense of deprivation. Encouraging the use of pressurized irrigation systems by the downstream farmers would also help to overcome their water scarcity. Rain water harvesting by raising the height of dykes of the fields should be encouraged [15] to increase groundwater recharge.

Recently, the Government of Pakistan has initiated irrigation reforms such as the participatory irrigation management (PIM) of the farmers. In these reforms emphases has been given to the tail-end farmers by giving them more representation in the water users organizations. Seepage losses have been ignored altogether under the existing criteria to allocate canal water at the tertiary level in the sub-continent of Pakistan and India $[3,5,10,12]$. This is the main cause of inequity between the head and tail-enders. To rectify this issue, canal water allocation criteria may be changed from the constant time per unit irrigated land to the variable time as proposed in the above studies.

\section{References}

[1] Kuper M, Kijne, J.W. Irrigation management in the Fordwah Branch command area. Southeast Punjab, Pakistan. In Advancements in IIMI's Research 1992: a selection of papers presented at the Internal Program Review. International Irrigation Management Institute: Colombo; pp. 1-24, 1992.

[2] Bhutta, M.N., Van der Velde, E.J. Equity of water distribution along secondary canals in the Punjab, Pakistan. Irrigation and Drainage Systems 6: pp. 161-177, 1992.

[3] Latif, M., Sarwrar S. Proposal for equitable water allocation for rotational irrigation in Pakistan. Journal of Irrigation and Drainage Systems 8: pp. 3548, 1994. 
[4] Habib Z, and Kuper M. Performance assessment of an irrigation system: application to Fordwah branch canal system. In: Proceedings of the National Conference in Managing Irrigation for Environmentally Sustainable Agriculture in Pakistan, Islamabad, Vol. 2, pp. 30-61, 1996.

[5] Khepar, S.D., Gulati, H.S., Yadav, A.K., \& Brar, T.P.S. A model for equitable distribution of canal water. Journal of Irrigation Science 19: pp. 191-197, 2000.

[6] UNDP. Human development report 2006, beyond scarcity: power, poverty and the global water crisis. United Nations Development Programme, New York, USA, 2006.

[7] Latif, M. Spatial productivity along a canal irrigation system in Pakistan. Journal of International Commission on Irrigation and Drainage (ICID) 56(5): pp. 509-521, 2007.

[8] Hussain, I., Sakthivadivel, R., \& Amarasinghe, U. Land and water productivity of wheat in the western Indo-Gangetic plains of India and Pakistan: a comparative analysis. In: Water Productivity in Agriculture: Limits and Opportunities for Improvement, Kijne JW, Barker R, Molden D (eds). CABI Publishing in association with the International Management Institute, Colombo, Sri Lanka; pp. 255-274, 2003.

[9] Bhattarai, M., Sakthivadivel, R., \& Hussain, I. Irrigation impacts on income inequality and poverty alleviation. Policy issues and options for improved management of irrigation systems. IWMI Working Paper 39. International Water Management Institute, Colombo, Sri Lanka, 2002.

[10] Sharma, D.N., \& Oad, R. variable time model for equitable irrigation water distribution. Agricultural water Management Journal 17: pp. 367-377, 1990.

[11] Malhotra, S.P. The warabandi and its infrastructure. Central Board of Irrigation and Power, New Delhi, India Publication No. 157, 1982.

[12] Latif, M. A variable time model for equitable distribution of canal water. In: Proceedings of the 1st International Conference on Sustainable Water Management in Developing Countries (SWM2010), Mehran University of Engineering and Technology, Jamshoro, Hyderabad, Pakistan, pp. 321-330, 2010.

[13] FAO. Water quality for agriculture, Irrigation and Drainage Paper No. 29 (Rev. I), 1985.

[14] Latif, M., \& Ahmad, M. Z. Integrated water resources management for sustainable development in a selected canal command in Pakistan. CEWRE Research Report No. 26, pp. 1-151, 2007.

[15] Kumar, Krishan and S. K. Gupta. Decline of groundwater tables in the upper Yamuna basin: causes and management strategies. Journal of the International Commission on Irrigation and Drainage, 59(5), pp. 606-620, 2010 . 